\title{
Physical Self-Concept and Motor Self-Efficacy Are Related to Satisfaction/Enjoyment and Boredom in Physical Education Classes
}

\author{
Verónica Morales-Sánchez ${ }^{1}$, Jacobo Hernández-Martos ${ }^{1}$, Rafael E. Reigal ${ }^{1, *(\mathbb{D})}$, Juan P. Morillo-Baro ${ }^{1}$ (D), \\ Montserrat Caballero-Cerbán ${ }^{2}$ and Antonio Hernández-Mendo ${ }^{1}$ (D) \\ 1 Faculty of Psychology, University of Malaga, 29071 Malaga, Spain; vomorales@uma.es (V.M.-S.); \\ jacobohm@uma.es (J.H.-M.); juanpablo.morillo@gmail.com (J.P.M.-B.); mendo@uma.es (A.H.-M.) \\ 2 EADE Center, University of Wales Trinity Saint David, 29018 Malaga, Spain; montserratcaballero@eade.es \\ * Correspondence: rafareigal@uma.es
}

Citation: Morales-Sánchez, V.; Hernández-Martos, J.; Reigal, R.E.; Morillo-Baro, J.P.; Caballero-Cerbán, M.; Hernández-Mendo, A. Physical Self-Concept and Motor Self-Efficacy Are Related to Satisfaction/

Enjoyment and Boredom in Physical Education Classes. Sustainability 2021, 13, 8829. https://doi.org/ $10.3390 /$ su13168829

Academic Editor: José

Carmelo Adsuar Sala

Received: 18 May 2021

Accepted: 3 August 2021

Published: 6 August 2021

Publisher's Note: MDPI stays neutral with regard to jurisdictional claims in published maps and institutional affiliations.

Copyright: (c) 2021 by the authors. Licensee MDPI, Basel, Switzerland. This article is an open access article distributed under the terms and conditions of the Creative Commons Attribution (CC BY) license (https:/ / creativecommons.org/licenses/by/ $4.0 /)$.

\begin{abstract}
Physical education (PE) classes promote extracurricular physical activity (PA). Therefore, having fun in this context is important for developing active lifestyles. The purpose of this study was to analyze the relationships between motor self-efficacy and physical self-concept with enjoyment/satisfaction and boredom in school PE lessons. A total of 195 adolescents aged 14 to 15 years $(M=14.65 ; \mathrm{SD}=0.48)$ from the city of Malaga participated. The Motor Self-Efficacy Scale (MSES), the Children Physical Self Questionnaire (C-PSQ) and the Sport Satisfaction Instrument (SSI) were used to evaluate the variables under study. Correlation and multiple regression analyses were performed, finding positive and statistically significant associations between motor self-efficacy and physical self-concept with enjoyment/satisfaction in PE, as well as negative relationships with boredom. Specifically, motor self-efficacy and perceived physical competence were predictors of satisfaction or boredom in PE. The results suggest that some physical and motor self-perceptions at these ages could contribute to developing attitudes towards physical practice in this type of educational context, in addition to the importance that their extrapolation to other contexts of PA outside school hours could have.
\end{abstract}

Keywords: self-efficacy; self-concept; satisfaction; boredom; adolescence

\section{Introduction}

School is a context that can favor the promotion of healthy lifestyles during adolescence [1]. Specifically, physical education (PE) classes constitute a fundamental vehicle to increase physical activity (PA) levels, directly and indirectly [2,3]. On the one hand, although a certain amount of PA is performed during these classes, they do not always reach the levels recommended by the World Health Organization for certain age groups $[4,5]$. However, it does not cease being highly relevant, given that this constitutes the only time that many adolescents engage in PA throughout the week [6]. On the other hand, PE classes can motivate students to develop this behavior outside school hours, facilitating the promotion of PA habits [7]. In fact, several studies have indicated that PA during school hours is linked to a higher level of PA outside school [7].

Given that there are multiple benefits of promoting active lifestyles on the physical and psychological health of adolescents [8,9], and that PE hours are limited, the role of this discipline in promoting these behaviors is essential. In general, enjoyment and satisfaction with PA and sports is considered a predictor for adherence [10]. Specifically, it has been observed that there is a positive relationship between enjoyment and satisfaction in PE classes and practicing PA outside school hours [11]. Thus, a high level of satisfaction with these classes could condition the attitudes and behaviors of children and adolescents in their free time, modifying their leisure time habits and strengthening healthy lifestyles [12,13]. 
However, the perception of boredom in PE classes could have a direct impact on physical practice in that school environment, but also on the cessation or lack of adherence of children and adolescents in extracurricular spaces [14]. Therefore, making students feel comfortable and satisfied with this subject is a priority objective for teachers $[15,16]$.

Different studies have approached the reasons why adolescents enjoy PE classes or not $[17,18]$. For example, it has been described how a perceived motivational climate oriented to the task has a positive impact on this feeling of enjoyment or not, with ego-oriented attitudes having a negative impact [19]. It has also been observed that the satisfaction of basic psychological needs, such as autonomy or competence, positively predict satisfaction in PE [20,21]. Kalajas-Tilga et al. [22] explored the importance of motivational processes in PE classes, noting how enjoyment in PE classes was an essential component in students' intrinsic motivation processes, and its benefits in adherence to PA.

Likewise, it has been highlighted that self-perceptions of competence and ability could also impact enjoyment and satisfaction in PE classes. Among them, motor self-efficacy and physical self-concept could be highlighted. Motor self-efficacy refers to the sense of competence that people employ to successfully cope with motor situations. On the other hand, physical self-concept is a mental representation concerning personal physical characteristics [23,24]. It has been observed that both self-perceptions have a great impact on the initiation or cessation of behaviors in contexts of physical practice, as well as on the motivation which is generated towards this type of behavior $[25,26]$. In this sense, Fraile-García et al. [27] highlighted positive relationships between motor self-efficacy and enjoyment in PE classes in children and adolescents. On the other hand, Gouveia et al. [28] identified positive relationships between physical self-concept and enjoyment in PE classes. Previous studies have demonstrated that the attitude shown in PE classes is conditioned by aspects such as the self-perception of physical competence [29,30]. These studies explored this issue in very wide age ranges (for example, between 10 and 18 years, or between 10 and 22 years) $[27,28]$.

These types of adolescent self-perceptions have been based on multiple experiences, such as those developed in sports contexts in which they have participated throughout their lives [31,32]. Among them, many take place in school PE classes [33]. When a person feels more physically competent, they will face physical practice with greater security and confidence. Thus, if mistakes are made, it will be possible to recover and not attribute the mistake to a lack of skill. On the contrary, a low perception of ability will engender a permanently negative evaluation of PA and a fear of failure. Therefore, the activity performed will be less enjoyable, and there will be a tendency to not participate. Thus, there is a greater chance of an individual not enjoying it [34,35]. As a result, PE teachers have a responsibility for generating experiences that contribute to the positive development and empowerment of young people [36]. If this is not the case, in addition to not having fun during the classes, there will be no motivation to continue performing PA outside school [37].

Specifically, the transition between early and middle adolescence is a crucial life stage, because future habits and identity are being constructed, in addition to the fact that personal perceptions can be very influential. Therefore, it is very important to analyze problems pertaining to PA at these ages [38,39]. In addition, self-perceptions at these ages are subject to permanent fluctuations derived from lived experiences and how the adolescent assumes that changes will occur in life [40]. On the other hand, previous studies which have analyzed the relationship between self-efficacy and self-concept with enjoyment and satisfaction in PE classes have done so in very wide age ranges $[27,28]$. Given the fluctuation generated by self-perceptions throughout adolescence, we consider it necessary to focus on specific stages of adolescence.

Therefore, with the aim of analyzing how physical and motor self-perceptions may influence satisfaction with PE classes, the purpose of this work was to explore the relationships between physical self-concept and motor self-efficacy with enjoyment/satisfaction and boredom in PE classes in a group of adolescents aged between 13 and 14 years 
old. Therefore, in this study, our research questions were as follows: Will perceptions of self-efficacy and physical self-concept be positively related to enjoyment/satisfaction and boredom in PE classes? Will the scores of these self-perceptions predict the level of enjoyment/satisfaction and boredom in the context of PE?

\section{Materials and Methods}

\subsection{Participants}

A total of 195 adolescents from the city of Malaga (103 girls, $52.82 \%$; 92 boys, $47.18 \%$ ), aged between 13 and 14 years $(M=13.65 ; \mathrm{SD}=0.48)$ participated in this study. Students who were exempt from PE or those who were injured and were not taking part in the class were excluded from the study. In addition, even if adolescents were in the same grade, if they were younger than 13 or older than 14, they were not included in the study. The reason for this exclusion was to limit the age as much as possible; previous studies have suggested that there are fluctuations in self-concept throughout adolescence as a function of age [40]. These studies indicate that throughout adolescence, these scores change, probably due to individuals' personal and social development as they grow up (for example, physical changes, academic responsibility, affective relationships, etc.). It was assumed that limiting the age of the study sample would minimize the possible variability experienced throughout this stage of life. A non-probability and convenience sampling methodology was used, due to the availability of access to the participants in different schools.

\subsection{Measurements and Instruments}

(a) Motor Self-Efficacy Scale (MSES) [41,42]. This instrument was used to analyze the perception of motor self-efficacy in contexts of physical practice. Specifically, it evaluates the personal capacity to successfully carry out a motor action. It consists of 10 items, which report on various situations during the practice of physical sports activity, and a single factor (e.g., I am confident that I could effectively handle unexpected situations when practicing $P A$ ). It is answered with a four-option Likert scale, from 1 (do not agree at all) to 4 (totally agree). The internal consistency analysis showed a Cronbach's alpha of 0.84 .

(b) Children Physical Self Questionnaire (C-PSQ) [43]. The scale utilized was a Spanish adaptation of the original Physical Self-Perception Profile (PSPP) for young people by Fox and Corbin [44]. This tool was used to analyze the multidimensional physical self-concept. Specifically, it evaluates the personal perception of different physical aspects. It consists of 28 items (e.g., I usually feel a little uncomfortable in places where people are doing physical exercise and sport) and four factors: physical competence, physical attractiveness, physical strength and self-confidence. It is answered on a Likert scale with several response options, from 0 (strongly disagree) to 10 (strongly agree). The internal consistency analysis showed a Cronbach's alpha of 0.82 for physical competence, 0.78 for physical attractiveness, 0.73 for physical strength and 0.74 for self-confidence.

(c) Sport Satisfaction Instrument (SSI) [45], was employed in its Spanish version which has been adapted to school PE classes [46,47]. It consists of 8 items (e.g., I usually have fun practicing sport) and two factors-satisfaction/enjoyment and boredom. It is answered with a Likert scale, from 1 (strongly disagree) to 5 (strongly agree). The internal consistency analysis showed a Cronbach's alpha of 0.79 for satisfaction and 0.72 for boredom.

\subsection{Procedure}

The sample was recruited from three schools in the city of Malaga. All these schools were located in areas with similar socioeconomic characteristics, as well as similar PE curricula, equipment, and PE times. The schools were contacted to request permission from the school management. Subsequently, informed consent was obtained from parent/guardians so that their children could participate in the study. After this, the purpose of the study was explained to the students, indicating that it would be completely voluntary, and that the data would be anonymous. After agreeing to take part in the study, the participants 
were provided with more information. Throughout the research process, the principles established in the Declaration of Helsinki [48] were respected; approval was obtained from the ethics committee of the University of Malaga for carrying out the research.

The data were collected during one hour of PE in the classroom. The students completed the questionnaires in approximately $45 \mathrm{~min}$. One of the researchers explained in detail how they should carry out the tests so that there were no errors. During the completion of the questionnaires, our team answered any question that arose.

\subsection{Data Analysis}

The data were subjected to descriptive and inferential analyses. The normality of the data distributions was also tested by means of the Kolmogorov-Smirnov test. In addition, the reliability of the different scales used was analyzed by evaluating internal consistency (Cronbach's alpha). To analyze the correlations between the measures considered, the Pearson bivariate coefficient was used, taking into account the parameters described by Evans [49] ( \pm 0.01 to \pm 0.19 = very weak correlation; \pm 0.20 to \pm 0.39 = weak correlation; \pm 0.40 to \pm 0.59 = moderate correlation; \pm 0.60 to \pm 0.79 = high correlation). In addition, to reduce the statistical error caused by multiple analysis, the Bonferroni correction was used on the set of correlations shown. On the other hand, the predictive capacity of motor self-efficacy and physical self-concept on the level of satisfaction and boredom in PE classes was evaluated by multiple regression analysis, using the stepwise technique (which adds or eliminates possible predictive variables, analyzing the statistical significance successively). For the statistical processing of the data, SPSS version 20.0 was used.

\section{Results}

Table 1 shows the descriptive statistics of the variables considered, as well as the normality analyses of the data. In addition, a Kolmogorov-Smirnov test was performed, which indicated that the data had a normal distribution. Data normality was determined when skewness and kurtosis were between -2 and 2, and if the Kolmogorov-Smirnov test was not significant. As can be seen, the distribution of the data was normal in all variables.

Table 1. Descriptive statistics for the variables of motor self-efficacy, physical self-concept, boredom and satisfaction in PE classes.

\begin{tabular}{lccccc}
\hline \multicolumn{1}{c}{ Study Variables } & M & SD & Skewness & Kurtosis & K-S \\
\hline Motor self-efficacy & 3.07 & 0.36 & -0.26 & -0.66 & 0.11 \\
Physical competence & 5.59 & 1.36 & -0.08 & 0.70 & 0.08 \\
Physical attractiveness & 4.62 & 1.49 & 1.31 & 1.44 & 0.04 \\
Physical strength & 5.21 & 1.30 & 0.55 & 1.53 & 0.10 \\
Self-confidence & 5.57 & 1.39 & 0.73 & -0.29 & 0.02 \\
Satisfaction in the PE & 3.93 & 0.61 & 0.02 & -1.14 & 0.11 \\
Boredom in PE & 1.80 & 0.87 & 0.46 & -1.33 & 0.07 \\
\hline
\end{tabular}

Note: K-S, Kolmogorov-Smirnov test.

Table 2 shows the Pearson correlations established between the variables.

Table 2. Pearson correlation levels between motor self-efficacy and physical self-concept with boredom and satisfaction in PE classes.

\begin{tabular}{lcc}
\hline & Satisfaction in PE & Boredom in PE \\
\hline Motor self-efficacy & $0.41^{* * *}$ & $-0.50^{* * *}$ \\
Physical competence & $0.47^{* * *}$ & $-0.49^{* * *}$ \\
Physical attractiveness & $0.28^{* *}$ & -0.14 \\
Physical strength & $0.35^{* * *}$ & $-0.22^{*}$ \\
Self-confidence & $0.38^{* * *}$ & $-0.39^{* * *}$ \\
\hline$* 00.05^{* *} p<0.01^{* * *} p<0.001$ &
\end{tabular}

${ }^{*} p<0.05$;** $p<0.01$; ${ }^{* * *} p<0.001$. 
Correlation analyses indicated significant values in the associations of most variables, with the exception of the relationships between physical attractiveness and boredom in PE classes. As shown in Table 2, motor self-efficacy and physical competence exhibited moderate correlations with satisfaction and boredom in PE classes. The analyses also indicated that there were weak correlations between physical attractiveness, physical strength and self-confidence with satisfaction and boredom.

Table 3 shows the multiple regression analyses performed (stepwise technique). Some variables were excluded from the models due to a lack of significance $(p>0.05)$. The results met the assumptions of model acceptance, such as linearity in the relationship between predictor variables and criteria, as well as homoscedasticity and normal distribution of the residuals, whose mean value was 0 and standard deviation was practically $1(0.99)$. In addition, the Durbin-Watson values were adequate, because they were in a range between 1.59 and 1.68. Pardo and Ruiz [50] considered that when the statistic is between 1.5 and 2.5 , it can be assumed that the residuals are independent, thus fulfilling the assumption of independence of the independent variables with respect to the dependent variable. On the other hand, the collinearity statistics indicated acceptable values of variance inflation (between 1.00 and 1.36) and of the tolerance index (between 0.73 and 1.00).

Table 3. Multiple regression models (stepwise technique) to analyze the predictive capacity of motor self-efficacy and physical self-concept on boredom and satisfaction in PE classes.

\begin{tabular}{|c|c|c|c|c|c|c|c|c|c|}
\hline $\begin{array}{l}\text { Criteria } \\
\text { Variables }\end{array}$ & $\mathbf{M}$ & $\mathbf{R}$ & $\mathbf{R} 2$ & D-W & $\begin{array}{l}\text { Variables } \\
\text { Predictors }\end{array}$ & B & $\mathbf{t}$ & $\mathbf{T}$ & IVF \\
\hline \multirow{5}{*}{$\begin{array}{l}\text { Satisfaction in the } \\
\text { PE }\end{array}$} & 1 & 0.47 & 0.22 & 1.59 & (Constant) & & $16.73^{* * *}$ & & \\
\hline & & & & & Physical competence & 0.47 & $7.36^{* * *}$ & 1.00 & 1.00 \\
\hline & 2 & 0.50 & 0.25 & 1.59 & (Constant) & & $5.92 * * *$ & & \\
\hline & & & & & Physical competence & 0.36 & $4.88^{* * *}$ & 0.73 & 1.36 \\
\hline & & & & & Motor self-efficacy & 0.22 & $3.01 * *$ & 0.73 & 1.36 \\
\hline \multirow{5}{*}{ Boredom in PE } & 1 & 0.50 & 0.25 & 1.68 & (Constant) & & $11.79 * * *$ & & \\
\hline & & & & & Motor self-efficacy & -0.50 & $-7.93^{* * *}$ & 1.00 & 1.00 \\
\hline & 2 & 0.57 & 0.32 & 1.68 & (Constant) & & $12.23^{* * *}$ & & \\
\hline & & & & & Motor self-efficacy & -0.33 & $-4.78^{* * *}$ & 0.77 & 1.30 \\
\hline & & & & & Physical competence & -0.32 & $-4.57^{* * *}$ & 0.77 & 1.30 \\
\hline
\end{tabular}

Note:D-W, Durbin-Watson; T, tolerance index; IVF, variance inflation factor. ${ }^{* *} p<0.01 ;{ }^{* * *} p<0.001$.

As shown in Table 3, the analyses indicated that the factors of perceived competence and motor self-efficacy significantly predicted satisfaction scores in PE $(R=0.50$; corrected $\mathrm{R} 2=0.25 ; \mathrm{F}=32.71 ; p<0.001)$. In this model, the physical competence predictor had a greater weight $(B=0.36)$ than motor self-efficacy $(B=0.22)$. Likewise, these same factors significantly predicted boredom scores in $\mathrm{PE}(\mathrm{R}=0.57$; corrected $\mathrm{R} 2=0.32 ; \mathrm{F}=45.09$; $p<0.001$ ), with a similar weight between them (motor self-efficacy, $\mathrm{B}=-0.33$; physical competence, $\mathrm{B}=-0.32$ ). Furthermore, in both models, the tolerance and variance inflation factor values were adequate, indicating there were no collinearity problems.

\section{Discussion}

The aim of the present study was to analyze the relationships between physical selfconcept and motor self-efficacy with enjoyment/satisfaction and boredom in PE classes in a group of adolescents. For this purpose, correlation analyses were performed between the variables, and multiple regression models were generated to determine the predictive capacity of self-efficacy and self-concept on measures of enjoyment/satisfaction and boredom in PE classes.

Firstly, the results have highlighted statistically significant relationships between the considered variables. In general terms, higher motor self-efficacy and better physical self-concept have been linked to greater enjoyment and satisfaction, and less boredom 
in PE classes. This result satisfies the study objective and is congruent with previous studies that had highlighted the importance of these self-perceptions for having a better physical practice experience in the school context [29]. Navarro-Patón et al. [51] conducted a study in elementary school students in which they obtained similar results. These authors highlighted the importance of having a good self-perception to improve adherence to physical practice behaviors, in general, and to improve the level of enjoyment with PE classes, in particular. Among other reasons, those students who have better self-perceptions engage in classes, are encouraged by successes, are less affected by mistakes, and strive to learn new skills [34,35]. Thus, when they participate in PE classes, adolescents are likely to generate a mental scheme of what they can and cannot do. This conditions their behavior, causing pleasant or unpleasant expectations, which contribute to greater enjoyment and satisfaction or not with how they perform during these classes.

Specifically, the variables of motor self-efficacy and perceived physical competence were those with the highest correlations. This corresponds to the variables that were predictors of satisfaction and boredom in the multiple regression models, suggesting that these self-perceptions would be relevant for an optimal PE experience. In the context of physical self-perception, the perceptions of efficacy and competence possibly generate feelings in adolescents that they are capable of successfully facing motor challenges. In addition, this feeling may be conditioned by experiences that increase the security they have in their abilities. These results are similar to those found by Fraile-García et al. [27], who reported moderate-level correlations between motor self-efficacy and enjoyment in PE classes. Navarro et al. [51] highlighted that physical self-concept, especially the perception of physical fitness, was an essential factor for enjoyment in these classes. These perceptions are important and relevant; it has even been observed that the relationships between motor skills and the practice of PA are modulated by factors such as self-concept [52-55]. Therefore, it is possible that adolescents with adequate motor skills would not agree to engage in PA, or were not fully involved, due to a distorted perception of PA. Hence, taking these aspects into account is vital.

Some of the adolescents analyzed had a perception of low motor skills, and the physical aspects of the classes could influence their approaches to these types of tasks, developing a reluctance to expose themselves in public to certain physical tasks if they do not have the required skills [56,57]. This will cause them to feel permanently judged in PE classes, which will not be pleasant for them if they do not consider that they have enough skill to participate. In general, this is a stage of life in which the perception of the body, and its different manifestations, is essential for adequate psychosocial development and good adaptations to the environment [58]. If this is transferred to a context in which they have to demonstrate certain aspects related to physical performance, there will be conflicts if the students consider that they are not able to carry out tasks effectively. This could be an extension of the impact that these self-perceptions have on the psychological health of children and adolescents, which is important to assess at this age to improve psychosocial development and well-being [59].

In addition, improving adherence to physical practice behaviors through PE classes and, by extension, in other leisure time contexts, would reinforce the perceptions of selfconcept and self-efficacy that are so important at these ages [60]. Therefore, a virtuous circle would be generated in which better perceptions of self-concept and self-efficacy facilitate the enjoyment of and access to physical practice, and regular physical practice would contribute to reinforcing these personal evaluations. To achieve this objective, authors such as FraileGarcía et al. [27] advise not to encourage competitive environments in the classroom, to promote successful experiences and develop adequate social relationships, and to seek strategies that facilitate increases in the perception of motor efficacy in students. For the construction of aspects such as self-concept, it is essential to have positive experiences. If these experiences are of failure, and the people around the student contribute to reinforcing this idea, the interpretation of the situation will be negative, and the self-concept generated will be built in that direction [61]. 
This study has some limitations. Firstly, an assessment of physical condition that would allow us to contrast self-perceptions with the actual physical condition of the adolescents has not been carried out. In future research, these variables will be considered to analyze whether there is a modulating effect of self-concept and self-efficacy between the physical condition of the students and their perception of enjoyment/satisfaction or boredom in PE classes. Secondly, self-concept and self-efficacy may vary across different ages. It is proposed that subsequent studies should evaluate a wider age group to compare them, as well as to carry out longitudinal research to explore possible variations over the years and to understand its incidence in terms of enjoyment and satisfaction or boredom in PE classes. In addition, the results could be conditioned by family socioeconomic status, which should be addressed in future research.

The results obtained in this research highlight positive and statistically significant relationships between several factors of physical self-concept and motor self-efficacy with satisfaction in education classes, as well as negative relationships with boredom in these classes. Furthermore, the data have shown that strong and weak physical competence and motor self-efficacy predict satisfaction or boredom, respectively, in PE classes. These results suggest that some physical and motor self-perceptions could modulate attitudes towards physical education classes. Furthermore, this is relevant because they could contribute to the promotion of PA in this environment and in other leisure time contexts.

Author Contributions: Conceptualization, J.H.-M., R.E.R., J.P.M.-B., M.C.-C., A.H.-M. and V.M.-S.; Methodology, J.H.-M., R.E.R., A.H.-M. and V.M.-S.; Software, A.H.-M. and V.M.-S.; Validation, J.H.-M., J.P.M.-B., M.C.-C., A.H.-M. and V.M.-S.; Formal analysis, R.E.R., J.P.M.-B., M.C.-C. and A.H.-M.; Data curation, J.H.-M. and M.C.-C.; Writing-original draft preparation, J.H.-M., R.E.R., J.P.M.-B., M.C.-C., A.H.-M. and V.M.-S.; Writing-review and editing, J.H.-M., R.E.R., J.P.M.-B., M.C.-C., A.H.-M. and V.M.-S.; Visualization, J.H.-M., R.E.R., J.P.M.-B., M.C.-C., A.H.-M. and V.M.-S.; Project administration, J.H.-M., A.H.-M. and V.M.-S. All authors made substantial contributions to the final manuscript. All authors have read and agreed to the published version of the manuscript.

Funding: This research received no external funding.

Institutional Review Board Statement: The study was conducted according to the guidelines of the Declaration of Helsinki, and approved by the Ethics Committee of University of Málaga.

Informed Consent Statement: Informed consent was obtained from all subjects involved in the study.

Conflicts of Interest: The authors declare no conflict of interest.

\section{References}

1. Arufe-Giráldez, V.; Barcala-Furelos, R.; Mateos-Padorno, C. Programas de deporte escolar en España e implicación de los agentes educativos. Rev. Int. Med. Cienc. Act. 2017, 67, 397-411. [CrossRef]

2. Abarca-Sos, A.; Pardo, B.M.; Clemente, J.A.J.; Casterad, J.Z.; Lanaspa, E.G. La Educación Física: ¿Una oportunidad para la promoción de la actividad física? Retos 2015, 28, 155-159. [CrossRef]

3. Kirk, D. Physical education-as-health promotion: Recent developments and future issues. Educ. Health 2018, 36, 70-75.

4. Hollis, J.L.; Sutherland, R.; Williams, A.J.; Campbell, E.; Nathan, N.; Wolfenden, L.; Morgan, P.J.; Lubans, D.R.; Gillham, K.; Wiggers, J. A systematic review and meta-analysis of moderate-to-vigorous physical activity levels in secondary school physical education lessons. Int. J. Behav. Nutr. Phys. Act. 2017, 14, 1-26. [CrossRef]

5. Mayorga-Vega, D.; Saldías, M.P.; Viciana, J. Niveles objetivos de actividad física durante las clases de Educación Física en estudiantes chilenos usando acelerometría Objectively measured physical activity levels during Physical Education lessons in Chilean students using accelerometry. Retos 2019, 37, 123-128. [CrossRef]

6. Moreno, L.; Concha, F.; Kain, J. Intensidad de movimiento de escolares durante clases de educación física de colegios municipales: Resultados según el profesional que efectúa las clases. Rev. Chil. Nutr. 2012, 39, 123-128. [CrossRef]

7. Silva, D.A.S.; Chaput, J.-P.; Katzmarzyk, P.; Fogelholm, M.; Hu, G.; Maher, C.; Olds, T.; Onywera, V.; Sarmiento, O.L.; Standage, M.; et al. Physical Education Classes, Physical Activity, and Sedentary Behavior in Children. Med. Sci. Sports Exerc. 2018, 50, 995-1004. [CrossRef]

8. Biddle, S.J.; Ciaccioni, S.; Thomas, G.; Vergeer, I. Physical activity and mental health in children and adolescents: An updated review of reviews and an analysis of causality. Psychol. Sport Exerc. 2019, 42, 146-155. [CrossRef] 
9. Messing, S.; Rütten, A.; Abu-Omar, K.; Ungerer-Röhrich, U.; Goodwin, L.; Burlacu, I.; Gediga, G. How Can Physical Activity Be Promoted Among Children and Adolescents? A Systematic Review of Reviews Across Settings. Front. Public Health $2019,7,55$. [CrossRef]

10. Bonavolontà, V.; Cataldi, S.; Maci, D.; Fischetti, F. Physical activities and enjoyment during the lockdown: Effect of home-based supervised training among children and adolescents. J. Hum. Sport Exerc. 2020, 15, S1338-S1343. [CrossRef]

11. Gråstén, A.; Jaakkola, T.; Liukkonen, J.; Watt, A.; Yli-Piipari, S. Prediction of Enjoyment in School Physical Education. J. sports Sci. Med. 2012, 11, 260-269.

12. Lwin, M.O.; Malik, S. The efficacy of exergames-incorporated physical education lessons in influencing drivers of physical activity: A comparison of children and pre-adolescents. Psychol. Sport Exerc. 2012, 13, 756-760. [CrossRef]

13. Taylor, I.M.; Ntoumanis, N.; Standage, M. A Self-Determination Theory Approach to Understanding the Antecedents of Teachers' Motivational Strategies in Physical Education. J. Sport Exerc. Psychol. 2008, 30, 75-94. [CrossRef] [PubMed]

14. Slutzky, C.B.; Simpkins, S. The link between children's sport participation and self-esteem: Exploring the mediating role of sport self-concept. Psychol. Sport Exerc. 2009, 10, 381-389. [CrossRef]

15. Gil-Arias, A.; Harvey, S.; Cárceles, A.; Práxedes, A.; Del Villar, F. Impact of a hybrid TGfU-Sport Education unit on student motivation in physical education. PLoS ONE 2017, 12, e0179876. [CrossRef] [PubMed]

16. Martínez, A.H.; Martí, I.G.; Matas, Y.S.; Olivares, S.C. Los ambientes de aprendizaje en Educación física y motivación en las primeras edades. Retos 2019, 38, 761-767. [CrossRef]

17. Papaioannou, A.; Milosis, D.; Gotzaridis, C. Interdisciplinary Teaching of Physics in Physical Education: Effects on Students' Autonomous Motivation and Satisfaction. J. Teach. Phys. Educ. 2020, 39, 156-164. [CrossRef]

18. Ruiz-Ariza, A.; Moral-García, J.E.; De la Torre-Cruz, M.J.; Grao-Cruces, A.; Martínez-López, E.J. Satisfaction of Spanish high school students with physical education: Gender, age, physical activity level and body type. S. Afr. J. Res. Sport Phys. Educ. Recreat. 2019, 40, 71-84.

19. Baena-Extremera, A.; Granero-Gallegos, A. Modelo de predicción de la satisfacción con la educación física y la escuela. Rev. Psicodidáctica 2014, 20, 177-192. [CrossRef]

20. Gómez-Rijo, A. Satisfacción de las necesidades psicológicas básicas en relación con la diversión y la desmotivación en las clases de educación física. Rev. Investig. Educ. 2013, 11, 77-85.

21. Sevil-Serrano, J.; Solana, A.A.; Catalán, Á.A.; González, L.G. El clima motivacional del docente de Educación Física: ¿Puede afectar a las calificaciones del alumnado? Retos 2016, 31, 98-102. [CrossRef]

22. Kalajas-Tilga, H.; Koka, A.; Hein, V.; Tilga, H.; Raudsepp, L. Motivational processes in physical education and objectively measured physical activity among adolescents. J. Sport Health Sci. 2020, 9, 462-471. [CrossRef]

23. Utesch, T.; Dreiskämper, D.; Naul, R.; Geukes, K. Understanding physical (in-) activity, overweight, and obesity in childhood: Effects of congruence between physical self-concept and motor competence. Sci. Rep. 2018, 8, 5908. [CrossRef] [PubMed]

24. Fernández-Bustos, J.-G.; González-Martí, I.; Contreras, O.; Cuevas, R. Relación entre imagen corporal y autoconcepto físico en mujeres adolescentes. Rev. Latinoam. Psicol. 2015, 47, 25-33. [CrossRef]

25. Arribas-Galarraga, S.; Cos, I.L.-D.; Cos, G.L.-D.; Urrutia-Gutierrez, S. Mediation Effect of Perceived Fitness on the Relationship between Self-Efficacy and Sport Practice in Spanish Adolescents. Int. J. Environ. Res. Public Health 2020, 17, 8800. [CrossRef]

26. Padial-Ruz, R.; Pérez-Turpin, J.A.; Cepero-González, M.; Zurita-Ortega, F. Effects of physical self-concept, emotional isolation, and family functioning on attitudes towards physical education in adolescents: Structural equation analysis. Int. J. Environ. Res. Public Health 2020, 17, 94. [CrossRef]

27. García, J.F.; Tejero-González, C.M.; Esteban-Cornejo, I.; Veiga, Ó.L. Asociación entre disfrute, autoeficacia motriz, actividad física y rendimiento académico en educación física. Retos 2018, 36, 58-63. [CrossRef]

28. Gouveia, É.R.; Ihle, A.; Gouveia, B.R.; Rodrigues, A.J.; Marques, A.; Freitas, D.L.; Kliegel, M.; Correia, A.L.; Alves, R.; Lopes, H. Students' Attitude Toward Physical Education: Relations With Physical Activity, Physical Fitness, and Self-Concept. Phys. Educ. 2019, 76, 945-963. [CrossRef]

29. Gu, X.; Zhang, T. Changes of Children's Motivation in Physical Education and Physical Activity: A Longitudinal Perspective. Adv. Phys. Educ. 2016, 06, 205-212. [CrossRef]

30. Howard, G.; Zeng, H.Z.; Hipscher, M.; Leung, R.W. Attitudes of High School Students toward Physical Education and Their Sport Activity Preferences. J. Soc. Sci. 2011, 7, 529-537. [CrossRef]

31. Mendo-Lázaro, S.; Polo-Del-Río, M.I.; Amado-Alonso, D.; Iglesias-Gallego, D.; León-Del-Barco, B. Self-Concept in Childhood: The Role of Body Image and Sport Practice. Front. Psychol. 2017, 8, 853. [CrossRef]

32. Beasley, E.K.; Garn, A.C. An Investigation of Adolescent Girls' Global Self-Concept, Physical Self-Concept, Identified Regulation, and Leisure-Time Physical Activity in Physical Education. J. Teach. Phys. Educ. 2013, 32, 237-252. [CrossRef]

33. Stiller, J.; Alfermann, D. Promotion of a Health Self-Concept. In Psychology for Physical Educators; Liukkonen, J., Auweele, Y.V., Vereijken, B., Alfermann, D., Theodorakis, Y., Eds.; Human Kinetics: Champaign, IL, USA, 2007; pp. $123-140$.

34. Haible, S.; Volk, C.; Demetriou, Y.; Höner, O.; Thiel, A.; Sudeck, G. Physical Activity-Related Health Competence, Physical Activity, and Physical Fitness: Analysis of Control Competence for the Self-Directed Exercise of Adolescents. Int. J. Environ. Res. Public Health 2019, 17, 39. [CrossRef]

35. Shen, B.; McCaughtry, N.; Martin, J. The Influence of Self-Determination in Physical Education on Leisure-Time Physical Activity Behavior. Res. Q. Exerc. Sport 2007, 78, 328-338. [CrossRef] 
36. Trigueros, R.; Aguilar-Parra, J.M.; Cangas, A.J.; López-Liria, R.; Álvarez, J.F. Influence of Physical Education Teachers on Motivation, Embarrassment and the Intention of Being Physically Active During Adolescence. Int. J. Environ. Res. Public Health 2019, 16, 2295. [CrossRef] [PubMed]

37. Baños, R.; Marentes-Castillo, M.; Zamarripa, J.; Baena-Extremera, A.; Ortiz-Camacho, M.D.M.; Duarte-Félix, H. Satisfacción, aburrimiento e importancia de la educación física en la intención de realizar actividad física extraescolar en adolescentes mexicanos. Cuad. Psicol. Deporte 2019, 19, 205-215. [CrossRef]

38. Inchley, J.; Kirby, J.; Currie, C. Longitudinal Changes in Physical Self-Perceptions and Associations With Physical Activity During Adolescence. Pediatr. Exerc. Sci. 2011, 23, 237-249. [CrossRef] [PubMed]

39. Logan, S.; Webster, E.; Getchell, N.; Pfeiffer, K.A.; Robinson, L.E. Relationship Between Fundamental Motor Skill Competence and Physical Activity During Childhood and Adolescence: A Systematic Review. Kinesiol. Rev. 2015, 4, 416-426. [CrossRef]

40. Vicent, M.; Martín, N.L.-S.; Gonzálvez, C.; Inglés, C.J.; García-Fernández, J.M.; Gomis, N. Diferencias de género y edad en autoconcepto en estudiantes adolescentes chilenos. Rev. Psicol. 2015, 24, 1-16. [CrossRef]

41. Hernández, J.-L.; Velazquez, R.; Martínez, M.E.; Garoz, I.; López, C.; López, A. Frecuencia de actividad física en niños y adolescentes: Relación con su percepción de autoeficacia motriz, la práctica de su entorno social y su satisfacción con la Educación Física. Infanc. Aprendiz. 2008, 31, 79-92. [CrossRef]

42. Hernández-Álvarez, J.L.; Velázquez-Buendía, R.; Martínez-Gorroño, M.E.; Garoz Puerta, I.; Tejero-González, C. Escala de Autoeficacia Motriz: Propiedades psicométricas y resultados de su aplicación a la población escolar española. Rev. Psicol. Deporte 2011, 20, 13-28.

43. Moreno, J.A.; Cervelló, E.; Vera, J.A.; Ruiz, L.M. Physical self-concept of Spanish schoolchildren: Differences by gender, sport practice and levels of sport involvement. J. Educ. Hum. Dev. 2007, 1, 1-17.

44. Fox, K.R.; Corbin, C.B. The Physical Self-Perception Profile: Devlopment and Preliminary Validation. J. Sport Exerc. Psychol. 1989, 11, 408-430. [CrossRef]

45. Duda, J.L.; Nicholls, J.G. Dimensions of achievement motivation in schoolwork and sport. J. Educ. Psychol. 1992, 84, 290-299. [CrossRef]

46. Balaguer, I.; Atienza, F.L.; Castillo, I.; Moreno, Y.; Duda, J.L. Factorial structure of measures of satisfaction/interest in sport and classroom in the case of Spanish adolescents. In Proceedings of the 4th European Conference of Psychological Assessment, Lisbon, Portugal, 7-10 September 1997; p. 76.

47. Baena-Extremera, A.; Granero-Gallegos, A.; Bracho-Amador, C.; Pérez-Quero, F.J. Versión española del Sport Satisfaction Instrument (SSI) adaptado a la educación física. Rev. Psicodidáctica 2012, 17, 377-395. [CrossRef]

48. World Medical Association. World Medical Association Declaration of Helsinki: Ethical Principles for Medical Research Involving Human Subjects. JAMA 2013, 310, 2191-2194. [CrossRef]

49. Evans, J.D. Straightforward Statistics for the Behavioral Sciences; Thomson Brooks/Cole Publishing Co: Pacific Grove, CA, USA, 1996.

50. Pardo, A.; Ruiz, M.A. Data Analysis with SPSS 13 Base; McGraw Hill: Madrid, Spain, 2005.

51. Navarro-Patón, R.; Barreal-López, P.; Basanta-Camiño, S. Relación entre el autoconcepto físico y el disfrute en las clases de Educación Física en escolares de Educación Primaria. J. Sport Health Res. 2016, 8, 5-16.

52. Jekauc, D.; Wagner, M.O.; Herrmann, C.; Hegazy, K.; Woll, A. Does Physical Self-Concept Mediate the Relationship between Motor Abilities and Physical Activity in Adolescents and Young Adults? PLoS ONE 2017, 12, e0168539. [CrossRef]

53. Barnett, L.M.; Morgan, P.J.; Van Beurden, E.; Beard, J.R. Perceived sports competence mediates the relationship between childhood motor skill proficiency and adolescent physical activity and fitness: A longitudinal assessment. Int. J. Behav. Nutr. Phys. Act. 2008, 5, 1-12. [CrossRef] [PubMed]

54. Capio, C.M.; Eguia, K.F. Movement skills, perception, and physical activity of young children: A mediation analysis. Pediatr. Int. 2021, 63, 442-447. [CrossRef] [PubMed]

55. Zhang, T.; Lee, J.; Barnett, L.; Gu, X. Does Perceived Competence Mediate between Ball Skills and Children's Physical Activity and Enjoyment? Children 2021, 8, 575. [CrossRef]

56. López-Sánchez, A.; Martínez de Quel, O. Self-concept in secondary school students and its impact on academic performance in physical education. AGON: Int. J. Sport Sci. 2015, 5, 7-14.

57. MacPhail, A.; Halbert, J. We had to do intelligent thinking during recent PE: students' and teachers' experiences of assessment for learning in post-primary physical education. Assess. Educ. Princ. Policy Pract. 2010, 17, 23-39. [CrossRef]

58. Williams, J.M.; Currie, C. Self-Esteem and Physical Development in Early Adolescence. J. Early Adolesc. 2000, $20,129-149$. [CrossRef]

59. Ybrandt, H. The relation between self-concept and social functioning in adolescence. J. Adolesc. 2008, 31, 1-16. [CrossRef] [PubMed]

60. Garn, A.C.; Morin, A.J.S.; White, R.L.; Owen, K.B.; Donley, W.; Lonsdale, C. Moderate-to-vigorous physical activity as a predictor of changes in physical self-concept in adolescents. Health Psychol. 2020, 39, 190-198. [CrossRef] [PubMed]

61. Esnaola, I. Desarrollo del autoconcepto durante la adolescencia y principio de la juventud. Rev. Psicol. Gen. Aplic. 2005, 58, 265-277. 